\title{
Automatic Surveying System of the Geographical Feature Utilizing Newly Developed Long-distance and Angle Measuring Instrument without Target Prism
}

\author{
Yukihiro Tsukada*, Noriaki Aoyama*, Satoshi Maeda**, \\ Tamotsu Nozawa***, Keizo Shimazaki***, Minoru Kato****
}

* Public Works Reserch Institute, Ministry of Construction, 1 Oaza-asahi, Tsukuba, 305 JAPAN

** Advanced Construction Technology Center, 2-10-2 Otowa, Bunkyo-ku, Tokyo, 112 JAPAN

*** Aoki Corporation, 36-1 Oaza-kaname, Tsukuba, 300-26 JAPAN

**** Plant Engineering Group, Kawasaki Heavy Industries, Ltd., 3-1-1 Higashikawasaki-cho, Chuo-ku, Kobe, 650-91 JAPAN

\begin{abstract}
The Public Works Research Institute of the Ministry of Construction, having developed an automatic measuring system of construction progress amount in the earth work together with the Advanced Construction Technology Center, Aoki Corporation and Kawasaki Heavy Industries, Ltd., herein reports it.

- In the conventional method, measurement technicians are obliged to move with carring a target prism in measuring site and to measure and collect the distance and angle data of many points by the TOTAL STATION. This paper is to report our newly developped NON-PRISM distance and angle measuring instrument, the total measuring system with automatic scanning method and several effects for man-power saving and also securing the safety with using this system
\end{abstract}

\section{INTRODUCTION}

Recently in the earth work, while size-enlarging and performance-improving of construction machines are being promoted, the technical development for work management and quality control is not enough and it causes that much time and labor are required still now. Therefore, in the General Technology Development Project "The Development of New Construction Process Technology", we have been engaged in the technique development aiming at automating and rationalizing in this field. We have developed the distance measuring 
instrument without the target prism and integrated the measuring system, which is the automatic measuring system of the construction progress in the earth work and enables automatization and labour-saving

In this paper, we report on confirmation of it's applicability and the results compared with the conventional TOTAL-STATION, based on the performance confirming test on a single unit and the proof experiment using the NON-PRISM experimental model.

\section{OUTLINE OF SYSTEM CONFIGURATION}

\section{2-1 System Configuration}

The automatic measuring system is composed of the distance measuring and angle measuring instrument (hereinafter called NON-PRISM), a portable computer which controls the automatic scanning and collects measuring data, Joy Stick which is to operate the angle measuring instrument manually, the power source battery and the tripod. (Fig.2-1-1)

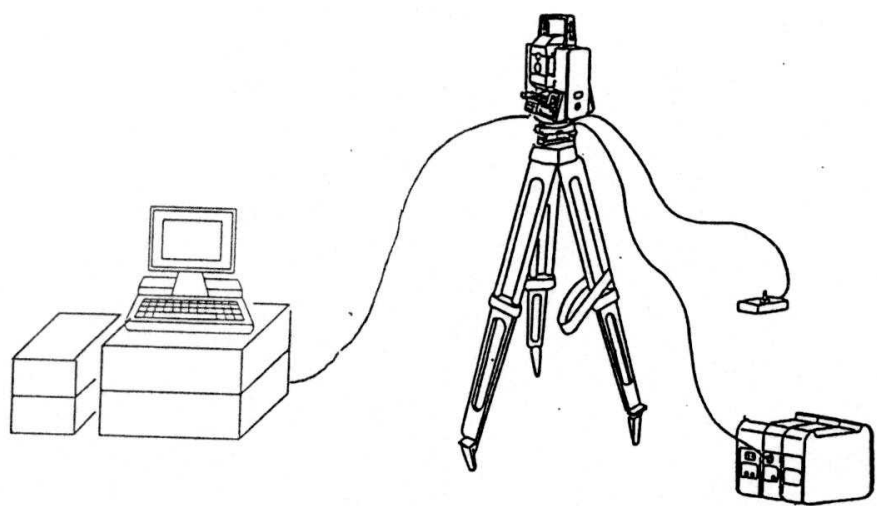

Fig. 2-1-1

Table 2-2-1 Setting of Automatic Measurement

\begin{tabular}{|l|l|l|}
\hline \multicolumn{1}{|c|}{ Setting Item } & \multicolumn{1}{|c|}{ Contents of Setting } & \multicolumn{1}{c|}{ Setting Method } \\
\hline $\begin{array}{l}\text { Setting of measuring } \\
\text { shape }\end{array}$ & (1) Polygon (2) Rectangle (3) Segment & Selection \\
\hline $\begin{array}{l}\text { Setting of } \\
\text { measured region }\end{array}$ & $\begin{array}{l}\text { Collimation range of telescope of an } \\
\text { angle measuring instrument }\end{array}$ & Joy Stick Operation \\
\hline $\begin{array}{l}\text { Setting of } \\
\text { scanning type }\end{array}$ & $\begin{array}{l}\text { (1) Angle } \\
\text { (2) Distance on ground surface }\end{array}$ & Selection \\
\hline $\begin{array}{l}\text { Setting of measured } \\
\text { pitch }\end{array}$ & $\begin{array}{l}\text { Angle : } 10^{\prime}, 30^{\prime}, 1^{\circ}, 2^{\circ}, 3^{\circ} \\
\text { Distance : } 0.3 \mathrm{~m}, 1.0 \mathrm{~m}, 2.0 \mathrm{~m}, 3.0 \mathrm{~m}, 4.0 \mathrm{~m}\end{array}$ & Selection \\
\hline
\end{tabular}




\section{2-2 Outline of Automatic Measuring}

Brief procedure for measuring and it's function are as follows;

(1) A operator will set the initial data to the computer listed up on Table 2-2-1 on previous page

(2)The computer starts and continues the automatic scanning for both horizontal and vertical direction respectively and successively.

(3) The computer will gather the inclined distance data, vertical angle and horizontal angle data for each measuring point per about five to eight seconds.

\section{PERFORMANCE OF DISTANCE AND ANGLE MEASURING INSTRUMENT}

\begin{tabular}{|c|c|c|}
\hline Item & Specifications & Remark \\
\hline $\begin{array}{l}\text { Distance measurement } \\
\text { section: } \\
\text { Distance } \\
\text { Accuracy } \\
\text { Time }\end{array}$ & $\begin{array}{l}20 \sim 1,000 \mathrm{~m} \\
\text { under } \pm 50 \mathrm{~mm} \\
\text { under } 0.4 \mathrm{sec} \text {. }\end{array}$ & $\begin{array}{l}\text { Reflection ratio: } 10 \% \\
\text { Visibility: } 7 \mathrm{~km} \text {, Vertical incidence } \\
\sigma \text {-value } \\
\text { Reflection ratio: } 10 \% \text {, } \\
\text { Visibility: } 7 \mathrm{~km} \text {, Vertical incidence }\end{array}$ \\
\hline $\begin{array}{l}\text { Angle measurement } \\
\text { section: } \\
\text { Accuracy } \\
\text { Range } \\
\text { Time }\end{array}$ & $\begin{array}{l}\text { Altitude : under } \pm 15^{\prime \prime} \\
\text { Horizontal : under } \pm 15^{\prime \prime} \\
\text { Depression: more than } 45^{\circ} \\
\text { Elevation: more than } 45^{\circ} \\
\text { Horizontal : Multi-rotation } \\
\text { under } 0.4 \mathrm{sec} \text {. }\end{array}$ & $\begin{array}{l}\text { Rotation in vertical } \\
\text { direction is possible. }\end{array}$ \\
\hline Remote operation & $\begin{array}{l}\text { Interface : RS232C } \\
\text { Baud rate : } 9600 \text { bps }\end{array}$ & \\
\hline Manual operation & Joy Stick & with ENTER KEY \\
\hline Electric power source & $12 \mathrm{~V} \mathrm{DC}, 8 \mathrm{~A}$ & Portable Battery \\
\hline Weight & $13 \mathrm{~kg}$ & Main body only \\
\hline
\end{tabular}




\section{PERFORMANCE OF SINGLE UNIT}

\section{4-1 Distance Measuring Accuracy}

(1) Test Contents

In a field circumstance, distance measuring accuracy of the NON-PRISM has been confirmed

\section{(2) Measuring Method}

In the test field, a target plate (a white board of A2 size) was placed at the arbitrary position about $50 \sim 800 \mathrm{~m}$ distance from the NON-PRISM.

The number of the measurement was about 100 times for each point and the average of those was converted to the horizontal distance. For the comparison with the true value, the horizontal distance between the same spots was also measured by the TOTAL-STATION (SET4DS made by SOKKIA Co.) and one element prism (APS-12S made by SOKKIA Co.), and used those data as the true value.

(3) Measured Result

The measured results concerning the distance measuring accuracy are shown in Table 4-1-1.

Table 4-1-1 Distance Measuring Accuracy

\begin{tabular}{|c|c|c|c|c|c|c|c|}
\hline \multicolumn{6}{|c|}{ NON-PRISM } & TOTAL STATION & Error \\
\hline \multirow{2}{*}{$\begin{array}{l}\text { Oblique } \\
\text { distance } \\
\mathrm{m}\end{array}$} & \multicolumn{3}{|c|}{ Vertical angle } & \multirow{2}{*}{$\begin{array}{r}\text { Converted hori- } \\
\text { zontal distance } \\
\mathrm{m}\end{array}$} & \multirow{2}{*}{$\begin{array}{l}\sigma \text { value } \\
\mathrm{m}(2)\end{array}$} & \multirow{2}{*}{$\begin{array}{l}\text { Horizontal } \\
\text { distance (true value) } \\
\mathrm{m}\end{array}$} & \multirow{2}{*}{ (1) $\quad$ m } \\
\hline & $\circ$ & , & $"$ & & & & \\
\hline 45.638 & 92 & 07 & 37 & 45.606 & 0.005 & 45.583 & 0.028 \\
\hline 85.500 & 91 & 28 & 36 & 85.472 & 0.004 & 85.448 & 0.028 \\
\hline 163.580 & 91 & 14 & 45 & 163.541 & 0.011 & 163.532 & 0.021 \\
\hline 196.591 & 91 & 04 & 32 & 196.557 & 0.008 & 196.533 & 0.032 \\
\hline 300.319 & 90 & 15 & 06 & 300.316 & 0.011 & 300.299 & 0.028 \\
\hline 399.805 & 90 & 09 & 58 & 399.803 & 0.009 & 399.773 & 0.039 \\
\hline 498.628 & 90 & 11 & 28 & 498.626 & 0.003 & 498.604 & 0.024 \\
\hline 598.686 & 90 & 10 & 00 & 598.684 & 0.006 & 598.675 & 0.015 \\
\hline 699.515 & 90 & 09 & 19 & 699.512 & 0.003 & 699.482 & 0.034 \\
\hline 802.472 & 89 & 34 & 30 & 802.450 & 0.004 & 802.437 & 0.017 \\
\hline
\end{tabular}

4-2 Distance Measuring Characteristics due to Inclined Surface Difference and Surface Material

\section{(1) Test Contents}

To investigate the infruence which the difference of inclined surface and it s material has on the distance measuring performance, the distance measuring characteristics were investigated by varying the incline angle versus to the laser axis of the sample plates made of differentrent material. 


\section{(2) Measuring Method}

The inclinable pedestal was used for the measurement.

This pedestal enable to incline the sample plate at arbitrary angle, and the sample plate was placed at $100 \mathrm{~m}$ distant from the NON-PRISM. Eight kinds of sample plates shown in Table 4-2-1 were prepared.

The distance at the angle of $0^{\circ}, 30^{\circ}, 60^{\circ}$ and $75^{\circ}$ were measured for each sample plate.

Table 4-2-1 Sample Plates

\begin{tabular}{|l|l|}
\hline Name of Sample & \multicolumn{1}{|c|}{ Material and Shape adhered on wooden panel } \\
\hline White board & White decorative sheet, highly mirror-like \\
\hline Black board & Black decorative sheet, highly mirror-like \\
\hline Earth & Earth, dry and wet condition prepared \\
\hline Sand & Sand, dry and wet condition prepared \\
\hline Stone & Stone, dry and wet condition prepared \\
\hline Artificial lawn & Lawn, yellow green, thickness about $1.5 \mathrm{~cm}$. \\
\hline $\begin{array}{l}\text { External wall } \\
\text { material }\end{array}$ & Black external wall materia, like mortar finish. \\
\hline Plaster board & White plaster board, like mortar finish. \\
\hline
\end{tabular}

(3) Measured Result

Based on a standard value at the inclin angle of zero degree, the difference of the measured distance in case of having varied the incline angle and the kind of the sample, are shown in Table4-2-2.

Table 4-2-2 Distance Measuring on Verious Sample Plates

\begin{tabular}{|lc|c|c|c|c|c|}
\hline \multirow{2}{*}{ Name of Sample } & \multicolumn{5}{|c|}{ Difference measured $\mathrm{m}$} & \multirow{2}{*}{ Remarks } \\
\cline { 3 - 6 } & & Inclined & angle & \multicolumn{1}{c|}{ (degree) } & \\
\cline { 3 - 6 } & 0 & 30 & 60 & 75 & \\
\hline White board & 100 & 0.00 & 0.00 & 0.00 & 0.00 & \\
\hline Black board & 100 & $0.00 \cdot$ & 0.00 & 0.00 & 0.00 & \\
\hline Earth (Dry) & 100 & 0.00 & 0.00 & 0.00 & 0.00 & \\
\hline Earth (Wet) & 100 & 0.00 & 0.00 & 0.00 & 0.00 & \\
\hline Sand (Dry) & 100 & 0.00 & 0.00 & 0.00 & -0.01 & \\
\hline Sand (Wet) & 100 & 0.00 & 0.00 & 0.00 & 0.00 & \\
\hline Stone (Dry) & 100 & 0.00 & 0.00 & 0.00 & 0.00 & \\
\hline Stone (Wet) & 100 & 0.00 & 0.00 & 0.00 & 0.00 & \\
\hline Artificial lawn & 100 & 0.00 & 0.00 & 0.00 & 0.00 & \\
\hline External wall material & 100 & 0.00 & 0.00 & 0.00 & 0.00 & \\
\hline Plaster board & 100 & 0.00 & 0.00 & 0.00 & -0.04 & \\
\hline White board & 340 & 0.00 & 0.00 & 0.00 & 0.00 & \\
\hline
\end{tabular}


Although this is the example of the considerably ideal object such as the flat plate, the variation of the measured distance due to the difference of the beam incidence angle (incline angle of the sample) were not found. And influences due to the difference among eight kinds of the prepared sample, were not also observed.

\section{PROOF EXPERIMENT}

The proof experiments were executed, for the purpose of carrying out the performance estimation by the measurement accuracy and to get the necessary man-power amount and also obtaining the basic data to analize the measurement characteristics and oerational requirement for this system through the measurement by the experiments in the fields.

In this paper, we pick up only the experimental result in which the comparison measuring was carried out with the TOTAL-STATION.

In addition, measured data collected by the NON-PRISM automatic measuring system, were converted to the coordinate data by the data managing program which had been developed at the same time, the coordinate data were separated into the elements of the triangle, using backup system of the civil engineering design which is placed on sale, the geography data were made and earth amount was calculated.

\section{5-1 Object Geography and Measurement Contents}

The experiments were executed as shown in Table 5-1-1 on next page.

\section{5-2 Earth Amount Measuring Accuracy}

In the NON-PRISM measuring system, many random points are automatically measured and after we can get the geography model (linear approximate model of the ground surface) by the element separation method which makes the measured points as nodal points. The earth amount before and after the geography variation can be obtained by quadrature between the geography model measured before and after the variation. The calculation accuracy of the earth amount by this method, depends on the accuracy of the geography model. In a common sense, the smaller the interval of the measuring point at the uniform distribution is made, the better becomes the accuracy of the geography model. The average section method and column state method and such are the same as this method on the basic concept.

In the experiment of this time, the estimation of the measured earth amount before and after the geography variation could not be done, from the restriction by the field and etc.

However, it was considered that the earth amount measuring accuracy can be verified indirectly, by estimating the approximate-accuracy of the geography model made from the result of the automatic measurement of the static geography. Then, on four cases of fairing face of slope (Data 1), created inclined face (Data2 and 3) and plain ground (Data 4), the approximate-accuracy of the model was estimated by the earth amount difference from the geography model measured by TOTAL-STATION (comparison object). However, the geography model by total station is not more than those which represents the measured amount accuracy by the conventional method, and not the geography model of the true value which $100 \%$ approximates to the object geography. 
The earth amount between the geographic model by the automatic measurement and total station are shown collectively in Table 5-2-1 on next page. In the table, the earth amount error per unit area is obtained. This is the same with the vertical error as a meaning, and the value of earth amount error is used to obtain the approximate calculated value of the measured earth amount error in case of measuring the similar geography.

Table 5-1-1 Object Geography of Experiment and Measuring Item

\begin{tabular}{|c|c|c|c|c|c|c|}
\hline & & \multicolumn{4}{|c|}{ NON-PRISM } & $\begin{array}{l}\text { TOTAL } \\
\text { STATION }\end{array}$ \\
\hline $\begin{array}{l}\text { Object Geo- } \\
\text { graphy }\end{array}$ & State of Geography & Distance & $\begin{array}{l}\text { Measured } \\
\text { Points }\end{array}$ & $\begin{array}{l}\text { Measured } \\
\text { Pitch } \\
\text { HA/VA }\end{array}$ & $\begin{array}{l}\text { Data } \\
\text { No }\end{array}$ & $\begin{array}{l}\text { Measured } \\
\text { Points }\end{array}$ \\
\hline $\begin{array}{l}\text { Fairing Face } \\
\text { of Slope }\end{array}$ & $\begin{array}{l}\text { Inclined face of cut ground } \\
\text { arranged in L letter form } \\
\text { Inclination : } 1: 0.8 \\
\text { Height } \quad: 20 \mathrm{~m} \\
\text { Width } \quad: 80 \mathrm{~m} \\
\text { Berm is of five-stage and face } \\
\text { of slope is faired. }\end{array}$ & 140 & 718 & $30^{\prime} / 30^{\prime}$ & Data 1 & 150 \\
\hline $\begin{array}{l}\text { Created } \\
\text { Inclined } \\
\text { Face }\end{array}$ & $\begin{array}{l}\text { Oblong inclined face under } \\
\text { creation } \\
\text { (Right side two third of inclined } \\
\text { face) } \\
\text { Inclination : } 1: 1 \\
\text { Height }: 20 \mathrm{~m} \\
\text { Width } \quad: 150 \mathrm{~m} \\
\text { Being faired roughly with } \\
\text { heavy machine } \\
\text { (Left side one third of inclined } \\
\text { face) } \\
\text { Slope unable to access }\end{array}$ & 500 & 213 & $\begin{array}{ll}30^{\prime} & / 10^{\prime} \\
30^{\prime} \quad / 10^{\prime}\end{array}$ & Data 2 & 63 \\
\hline Plain Ground & $\begin{array}{l}\text { Work yard under rough stone } \\
\text { mining surface } \\
\text { Plain surface of which area is } \\
\text { about } 100 \times 80 \mathrm{~m} \\
\text { State such that base rock is } \\
\text { slightly covered by sand. }\end{array}$ & 150 & 1002 & $30^{\prime} / 10^{\prime}$ & Data 4 & ----- \\
\hline $\begin{array}{l}\text { Accumulated } \\
\text { Wood Chip }\end{array}$ & $\begin{array}{l}\text { Heap of accumulated wood } \\
\text { chip. } \\
\text { Bottom area: } 100 \times 30 \mathrm{~m}, \\
\text { Height: } 10 \mathrm{~m}\end{array}$ & 40 & 2475 & $3^{\circ} / 30^{\prime}$ & Data 5 & $\begin{array}{l}\text { aerial } \\
\text { photograph }\end{array}$ \\
\hline
\end{tabular}


Table 5-2-1 Earth Amount Measuring Accuracy by Automatic Measurement

\begin{tabular}{|c|c|c|c|c|c|c|}
\hline object geography & $\begin{array}{l}\text { Cut } \\
\text { Ground } \\
\text { (1) } \mathrm{m}^{3}\end{array}$ & $\begin{array}{l}\text { Fill-up } \\
\text { Ground } \\
\text { (2) } \mathrm{m}^{3}\end{array}$ & $\begin{array}{l}\text { Tot } \\
\text { (3) }=\end{array}$ & $\begin{array}{l}\text { al (3) } \\
1 \text { (2) } \mathrm{m}^{3} \\
\end{array}$ & $\begin{array}{l}\text { Plain } \\
\text { Area } \\
\text { (4) } \mathrm{m}^{2}\end{array}$ & $\begin{array}{l}\text { Volume Error } \\
(5)=3 / 4\end{array}$ \\
\hline $\begin{array}{c}\text { Fairing face of slope } \\
\text { Data } 1\end{array}$ & 42.65 & 39.41 & & 2.06 & 1171.795 & 0.07 \\
\hline $\begin{array}{l}\text { Created inclined face } 1 \\
\text { Data } 2\end{array}$ & 386.82 & 316.47 & & 3.29 & 5088.161 & 0.14 \\
\hline $\begin{array}{l}\text { Created inclined face } 2 \\
\text { Data } 3\end{array}$ & 229.94 & 179.57 & & 9.69 & 2443.761 & 0.16 \\
\hline $\begin{array}{r}\text { Plain ground } \\
\text { Data } 4 \\
\end{array}$ & 11.88 & 3.22 & & 5.10 & 1483.121 & 0.01 \\
\hline $\begin{array}{l}\text { Accumulated wood chip } \\
\text { Data } 5\end{array}$ & \multicolumn{3}{|c|}{ Automatic Measurement } & Analysis & from Aeria & 1 Picture \\
\hline
\end{tabular}

\section{5-3 Object Geography}

The state picture of created inclined face of Data 2 and 3 (Picture 5-3-1) and the aerial view made from the measured value of accumulated wood chip Data 5 (Fig. 5-3-2) are shown below.
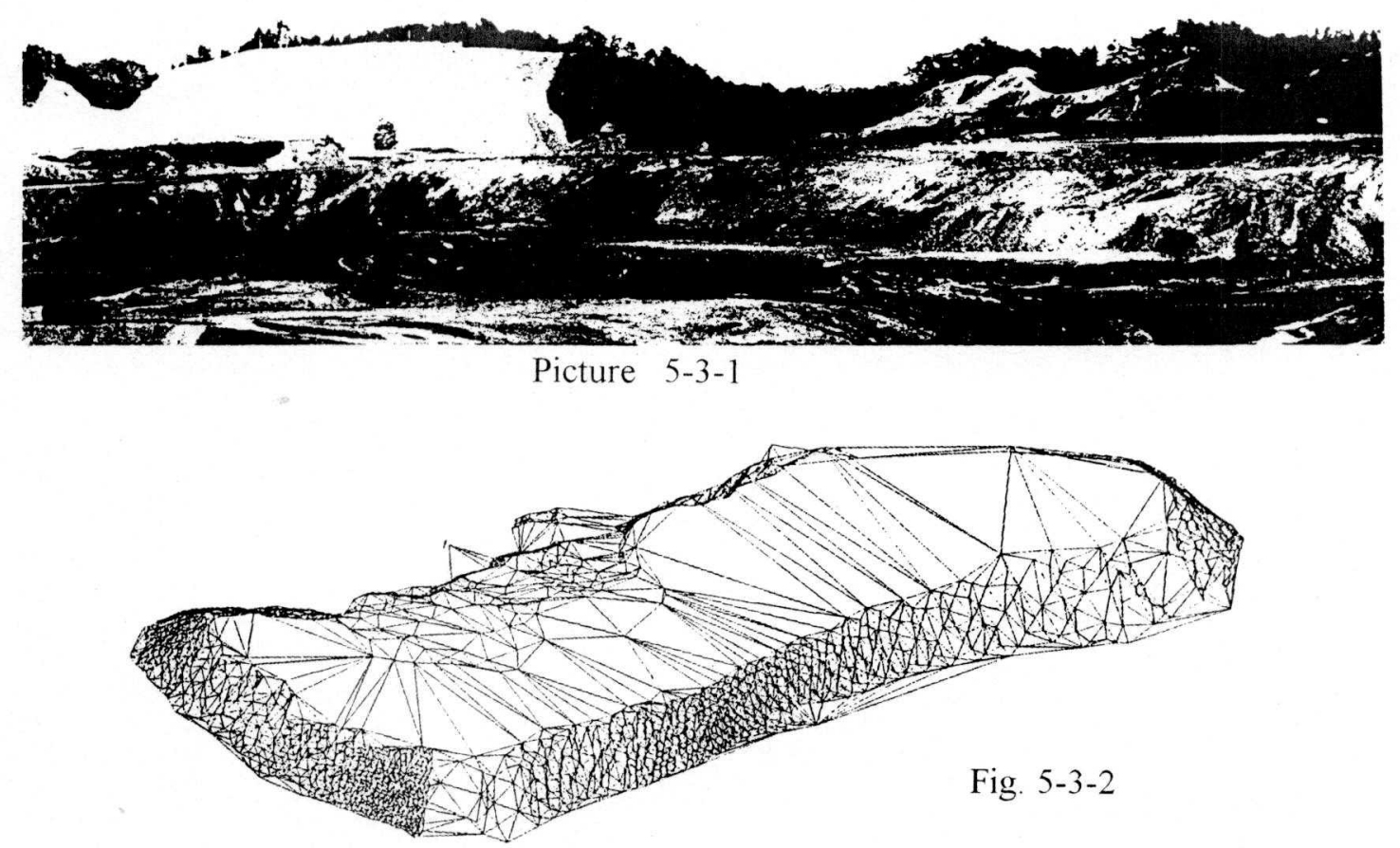

13th ISARC 


\section{EFFECTIVENESS OF SYSTEM 《MAN-POWER REDUCTION》}

\section{6-1 Unit Working Hour}

Throughout these experiments, a certain knowledge concerning the required hours of measuring work could be gotten. The required hours and required number of worker for each work item are shown collectively in Table 6-1-1.

Table 6-1-1 Comparison Table of Work Man-hour

\begin{tabular}{|c|c|c|c|}
\hline Work Item & $\begin{array}{l}\text { Required } \\
\text { Time } \\
\end{array}$ & $\begin{array}{l}\text { Required } \\
\text { Man Power } \\
\end{array}$ & Remarks \\
\hline $\begin{array}{l}\text { Measurement } \\
\text { Preparation }\end{array}$ & $15 \sim 20 \mathrm{~min}$ & $\begin{array}{l}1 \sim 2 \\
\text { workers }\end{array}$ & $\begin{array}{l}\text { - Installation of instrument } \\
\text { - Collimation of known point } \\
\text { - Setting of measurement range } \\
\text { and measuring pitch }\end{array}$ \\
\hline $\begin{array}{l}\text { Automatic } \\
\text { Measuring }\end{array}$ & $\begin{aligned} 5 \sim 8 \\
\text { sec/ point } \\
\end{aligned}$ & $\begin{array}{l}\text { Not } \\
\text { required }\end{array}$ & $\begin{array}{l}\text { Measuring time per one point changes } \\
\text { depending on measuring pitch }\end{array}$ \\
\hline $\begin{array}{l}\text { Battery } \\
\text { Chang }\end{array}$ & $\begin{array}{r}3 \sim 5 \mathrm{~min} / \\
\text { change } \\
\end{array}$ & 1 worker & Duration of battery is $1.5 \sim 2$ hours \\
\hline $\begin{array}{l}\text { Clearing } \\
\text { After Work }\end{array}$ & 5 minutes & $\begin{array}{l}1 \sim 2 \\
\text { workers }\end{array}$ & Removing equipment and etc. \\
\hline
\end{tabular}

\section{6-2 Comparison of Work Man-hour}

The comparison between the man-hour of the automatic measuring by NON-PRISM measuring system and the one by the existing method is made. The results of the work manhour of the fairing face of the slope and creating inclined face in which the comparison measurement is executed, are shown collectively in Table 6-2-1 on next page. Comparing with the existing method, the large number of the measured points (random points)could be obtained in the short time. And since no workers were needed to attend the measured spot, only a worker for operation of the instrument was required as the required number of the worker. Furthermore, this worker could be engaged in another work during the automatic measurement

It was confirmed that the measurement could be performed by man-hour of about a third, comparing with the conventional method. It is clear that the larger the range of the measurement becomes, the more remarkable becomes the effect of man-hour reduction.

\section{CONCLUSION}

Although we could not report in this paper, we have performed analysis also on the instrument installing accuracy, the error characteristics depending on the geography, measurement characteristics depending on the measuring position and the measurement pitch and the earth amount measuring accuracy etc.,. We can judge that this system gets basically required performance which is necessary and sufficient for many fields.

$$
-741-
$$


Especially for the measurement on the dangerous place such as the steep slope and the place unable to access, this system is one issue which displays might, and makes the safe measuring work possible.

Lastly, we would like to express many thanks to every member of ASCODE (Automatic

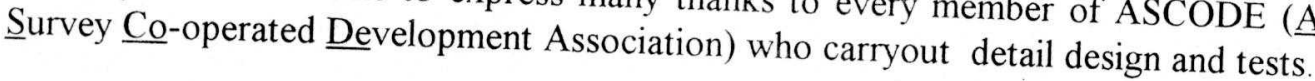

Table 6-2-1 Comparison Table of Work Man-hour

Fairing face of slope (Data 1)

\begin{tabular}{|l|l|l|l|l|c|}
\hline & $\begin{array}{l}\text { Form of } \\
\text { Measuring }\end{array}$ & $\begin{array}{l}\text { Required } \\
\text { Time (hr) }\end{array}$ & $\begin{array}{l}\text { Number of } \\
\text { Worker }\end{array}$ & Remarks & $\begin{array}{l}\text { Man-hour } \\
\text { ratio }\end{array}$ \\
\hline NON-PRISM & $\begin{array}{l}\text { Automatic } \\
\text { random } \\
\text { measuring }\end{array}$ & 1.5 & $1 *$ & $\begin{array}{l}\text { measuring points }=718 \\
\text { including preparation } \\
\text { time etc. 0.5hr }\end{array}$ & 0.375 \\
\hline $\begin{array}{l}\text { TOTAL- } \\
\text { STATION }\end{array}$ & $\begin{array}{l}\text { Section } \\
\text { measuring }\end{array}$ & 2. & 2 & measuring points = 150 & 1 \\
\hline
\end{tabular}

Created inclined face 1 (Data 2)

\begin{tabular}{|l|l|l|c|l|c|}
\hline & $\begin{array}{l}\text { Form of } \\
\text { Measuring }\end{array}$ & $\begin{array}{l}\text { Required } \\
\text { Time (hr) }\end{array}$ & $\begin{array}{l}\text { Number of } \\
\text { Worker }\end{array}$ & Remarks & $\begin{array}{l}\text { Man-hour } \\
\text { ratio }\end{array}$ \\
\hline NON-PRISM & $\begin{array}{l}\text { Automatic } \\
\text { random } \\
\text { measuring }\end{array}$ & 1.2 & $1^{*}$ & $\begin{array}{l}\text { measuring points = 486 } \\
\text { including preparation } \\
\text { time etc. 0.5hr }\end{array}$ & 0.267 \\
\hline $\begin{array}{l}\text { TOTAL- } \\
\text { STATION }\end{array}$ & $\begin{array}{l}\text { Section } \\
\text { measuring }\end{array}$ & 1.5 & 3 & $\begin{array}{l}\text { measuring points }=63 \\
\text { including section determi- } \\
\text { nation time, etc. 0.5hr }\end{array}$ & 1 \\
\hline $\begin{array}{l}\text { GPS } \\
\text { (Reference) }\end{array}$ & $\begin{array}{l}\text { Section } \\
\text { measuring }\end{array}$ & 0.75 & 2 & $\begin{array}{l}\text { Same points as the } \\
\text { TOTAL-STATION }\end{array}$ & 0.333 \\
\hline
\end{tabular}

Created inclined face -2 (Data 3 )

\begin{tabular}{|l|l|l|c|l|c|}
\hline & $\begin{array}{l}\text { Form of } \\
\text { Measuring }\end{array}$ & $\begin{array}{l}\text { Required } \\
\text { Time (hr) }\end{array}$ & $\begin{array}{l}\text { Number of } \\
\text { Worker }\end{array}$ & Remarks & $\begin{array}{l}\text { Man-hour } \\
\text { ratio }\end{array}$ \\
\hline NON-PRISM & $\begin{array}{l}\text { Automatic } \\
\text { random } \\
\text { measuring }\end{array}$ & 0.8 & $1 *$ & $\begin{array}{l}\text { Measuring points = 213 } \\
\text { including preparation } \\
\text { time etc. 0.5hr }\end{array}$ & 0.4 \\
\hline $\begin{array}{l}\text { TOTAL- } \\
\text { STATION }\end{array}$ & $\begin{array}{l}\text { Section } \\
\text { measuring }\end{array}$ & 1.0 & 2 & $\begin{array}{l}\text { measuring points }=50 \\
\text { including section determi- } \\
\text { nation time, etc. 0.5hr }\end{array}$ & 1 \\
\hline $\begin{array}{l}\text { GPS } \\
\text { Reference) }\end{array}$ & $\begin{array}{l}\text { Section } \\
\text { measuring }\end{array}$ & 0.5 & 2 & $\begin{array}{l}\text { Same points as the } \\
\text { TOTAL-STATION }\end{array}$ & 0.5 \\
\hline
\end{tabular}

* No men are required during automatic measuring 